Article

\title{
Hypoxic-Inflammatory Responses under Acute Hypoxia: In Vitro Experiments and Prospective Observational Expedition Trial
}

\author{
Tobias Kammerer ${ }^{1,2,3, * \mathbb{C}}$, Valentina Faihs ${ }^{2,3}\left(\mathbb{D}\right.$, Nikolai Hulde ${ }^{1,2}$, Manfred Stangl ${ }^{4}$, \\ Florian Brettner ${ }^{2,3}$, Markus Rehm ${ }^{2}$, Mareike Horstmann ${ }^{5}$, Julia Kröpfl ${ }^{6}$, \\ Christina Spengler ${ }^{6}\left(\mathbb{D}\right.$, Simone Kreth ${ }^{2,3}$ and Simon Schäfer $2,3, *$ (D) \\ 1 Institute of Anesthesiology, Heart and Diabetes Center NRW, Ruhr-University Bochum, Georgstr. 11, \\ 32545 Bad Oeynhausen, Germany; nhulde@hdz-nrw.de \\ 2 Department of Anaesthesiology, University Hospital, LMU Munich, 81377 Munich, Germany; \\ vfaihs@yahoo.de (V.F.); florian.brettner@med.uni-muenchen.de (F.B.); \\ markus.rehm@med.uni-muenchen.de (M.R.); simone.kreth@med.uni-muenchen.de (S.K.) \\ 3 Walter Brendel Centre of Experimental Medicine, LMU Munich, 81377 Munich, Germany \\ 4 Klinik für Allgemein-, Viszeral-, und Transplantationschirurgie, LMU Munich, 81377 Munich, Germany; \\ manfred.stangl@med.uni-muenchen.de \\ 5 Molecular Ophthalmology, Department of Ophthalmology, University of Duisburg-Essen, 45147 Essen, \\ Germany; mareike.horstmann@uk-essen.de \\ 6 Exercise Physiology Lab, Institute of Human Movement Sciences and Sport, ETH Zurich, 8057 Zurich, \\ Switzerland; julia.kroepfl@hest.ethz.ch (J.K.); christina.spengler@hest.ethz.ch (C.S.) \\ * Correspondence: tobias.kammerer@ruhr-uni-bochum.de (T.K.); \\ simon.schaefer@med.uni-muenchen.de (S.S.)
}

Received: 12 December 2019; Accepted: 1 February 2020; Published: 4 February 2020

\begin{abstract}
Induction of hypoxia-inducible-factor- $1 \alpha$ (HIF- $1 \alpha)$ pathway and HIF-target genes allow adaptation to hypoxia and are associated with reduced incidence of acute mountain sickness (AMS). Little is known about HIF-pathways in conjunction with inflammation or exercise stimuli under acute hypobaric hypoxia in non-acclimatized individuals. We therefore tested the hypotheses that (1) both hypoxic and inflammatory stimuli induce hypoxic-inflammatory signaling pathways in vitro, (2) similar results are seen in vivo under hypobaric hypoxia, and (3) induction of HIF-dependent genes is associated with AMS in 11 volunteers. In vitro, peripheral blood mononuclear cells (PBMCs) were incubated under hypoxic $\left(10 \% / 5 \% \mathrm{O}_{2}\right)$ or inflammatory $(\mathrm{CD} 3 / \mathrm{CD} 28)$ conditions. In vivo, Interleukin $1 \beta$ (IL-1 $\beta$ ), C-X-C Chemokine receptor type 4 (CXCR-4), and C-C Chemokine receptor type 2 (CCR-2) mRNA expression, cytokines and receptors were analyzed under normoxia (520 m above sea level (a.s.l.)), hypobaric hypoxia (3883 $\mathrm{m}$ a.s.l.) before/after exercise, and after $24 \mathrm{~h}$ under hypobaric hypoxia. In vitro, isolated hypoxic $(p=0.004)$ or inflammatory $(p=0.006)$ stimuli induced IL-1 $\beta$ mRNA expression. CCR-2 mRNA expression increased under hypoxia $(p=0.005)$; CXCR-4 mRNA expression remained unchanged. In vivo, cytokines, receptors, and IL-1 $\beta$, CCR- 2 and CXCR-4 mRNA expression increased under hypobaric hypoxia after $24 \mathrm{~h}$ (all $p \leq 0.05$ ). Of note, proinflammatory IL-1 $\beta$ and CXCR-4 mRNA expression changes were associated with symptoms of AMS. Thus, hypoxic-inflammatory pathways are differentially regulated, as combined hypoxic and exercise stimulus was stronger in vivo than isolated hypoxic or inflammatory stimulation in vitro.
\end{abstract}

Keywords: hypoxic-inflammatory response; hypobaric hypoxia; cytokines 


\section{Introduction}

Mammalian responses to hypoxia in combination with either inflammation or exercise stress, are highly related and induce the same hypoxia-inducible-factor- $1 \alpha$ (HIF-1 $\alpha$ ) signaling pathway [1-6]. In this regard, HIF- $1 \alpha$ and its target genes are the key regulators allowing to adapt or even counteract hypoxic or inflammatory conditions $[5,6]$.

Under normoxia, HIF- $1 \alpha$ is constantly built and within minutes degraded by the ubiquitin-proteasome system after hydroxylation by oxygen-dependent prolylhydroxylases and recognition by the von Hippel-Lindau protein [5]. However, when oxygen partial pressure decreases, activity of HIF-degrading prolinhydroxylases (PHD) drop and HIF is stabilized, dimerizes with HIF-1 $\beta$ [5], and induces the transcription of HIF-1 target genes to overcome hypoxia inducing erythropoiesis, vasodilatation, vascular growth, or release of various mediators [6,7].

In this regard, previous research mainly focused on cell-cultures in vitro or experiments using animals [8-11]. Thus, it is known that a single hypoxic or inflammatory stimulus in mammalian cells in vitro induces the HIF-1 $\alpha$ signaling pathway [8]. A preceding and repeated inflammatory stimulus can induce cellular tolerance, a phenomenon known from inflammatory disorders as lipopolysaccharid tolerance $[6,7,12,13]$. Tolerant cells lose their ability to induce HIF- $1 \alpha$ mRNA expression and cellular protein content even when a strong second stimulus is given [9]. This even applies to humans in the initial phase of severe sepsis, where surprisingly, HIF- $1 \alpha$ mRNA expression, cellular protein, and HIF-target genes are already highly decreased in leukocytes $[6,7,12,14]$. This inhibited HIF-pathway shows that immunosuppressive phenotypes are immediately initiated after the onset of sepsis $[6,7,12,14]$.

Of note, there is a high interindividual variability in expression of HIF and HIF target genes following inflammatory or hypoxic stimuli, which at least partially can be explained by genetic variants like single nucleotid polymorphisms. In this context, we have previously shown that additionally to the extent of hypoxic or inflammatory stimuli or their duration, genetic variants in HIF-1, HIF-2, and HIF-degrading PHD-2 alter human adaptation to hypoxia [15-19]. High altitude residents thus have blunted hypoxic ventilatory response and diminished pulmonary hypertension under hypoxia [20,21], increased heart rate, improved peripheral oxygen saturation, and reduced incidence of mountain sickness, as assessed using the Lake Louise Score (LLS) [15,16,22-24]. LLS, which has recently been revised, is a well-established tool to evaluate the severity of acute mountain sickness (AMS) [25,26]. However, little is known about possible associations between molecular hypoxic-inflammatory responses and AMS or increased LLS, respectively.

It is known that both exercise and hypoxia can alter mRNA expression and protein release of pro- and anti-inflammatory cytokines, like interleukin-1 $\beta$ (IL-1 $\beta$ ), IL-6, or IL-10, activate lymphocytes, alter chemokine receptors, or induce further signaling pathways of the hypoxic inflammatory response [27-29]. Especially, in high altitude cerebral edema (HACE) proinflammatory cytokines like IL-1 $\beta$, IL-6, or vascular endothelial growth factor A (VEGF-A) are believed to play an important role [30,31]. Apart from pro- and anti-inflammatory cytokines, the role of chemokines is of particular importance, as chemokine expression and its ligands are crucial for immune cell migration, e.g., in neuroinflammatory processes, and could therefore also be of interest with respect to hypobaric hypoxia-induced AMS and high altitude cerebral edema (HACE) [32-34].

In summary, we know that the HIF-pathway is induced by hypoxia and by inflammation and exercise stimuli. However, little is known about in vivo responses to hypoxia and exercise on regulation of HIF-dependent pathways in healthy individuals, e.g., mountaineers. In this prospective observational trial, we first analyzed in vitro the effects of hypoxic and inflammatory stimuli on HIF-pathway genes and cytokines released in peripheral blood mononuclear cells (PBMCs) from healthy non-acclimatized volunteers. These volunteers then participated in an expedition trial that involved significant changes in oxygen concentrations in which we again analyzed HIF-pathway genes, inflammatory markers, clinical variables, and LLS at intervals following exposure to acute hypobaric hypoxia. 
Thus, we tested the hypotheses that 1) hypoxic and inflammatory stimuli both induce hypoxic-inflammatory signaling pathways in vitro, 2) similar results are seen in vivo under hypobaric hypoxia, and 3) that induction of HIF-dependent genes is associated with AMS.

\section{Results}

\subsection{Induction of Hypoxic-Inflammatory Pathways}

In this study, blood smears were performed both at baseline (Munich $520 \mathrm{~m}$ above sea level (a.s.l.)) and after $24 \mathrm{~h}$ under hypobaric hypoxia (Little Matterhorn summit at $3883 \mathrm{~m}$ a.s.l.). Following hypobaric hypoxia, cells show increased amount of intracellular HIF- $1 \alpha$ protein compared to baseline (see Figure 1). Thus, our data show, that the exposure to hypobaric hypoxia was sufficient to induce hypoxic-inflammatory pathways.
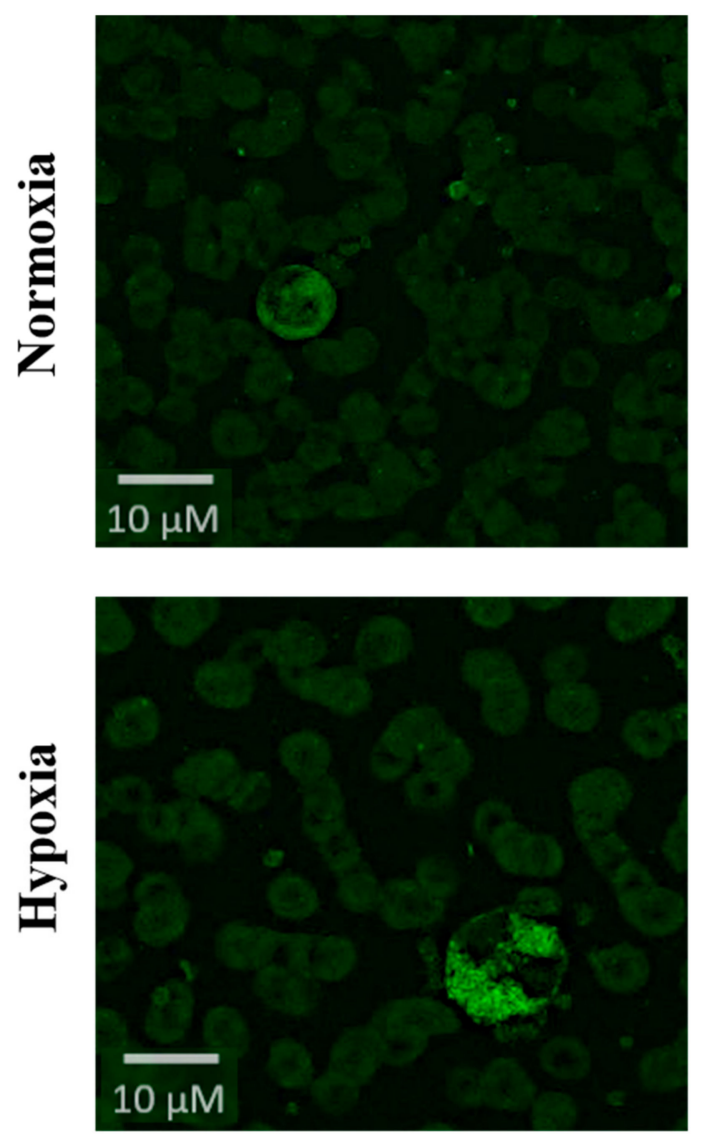
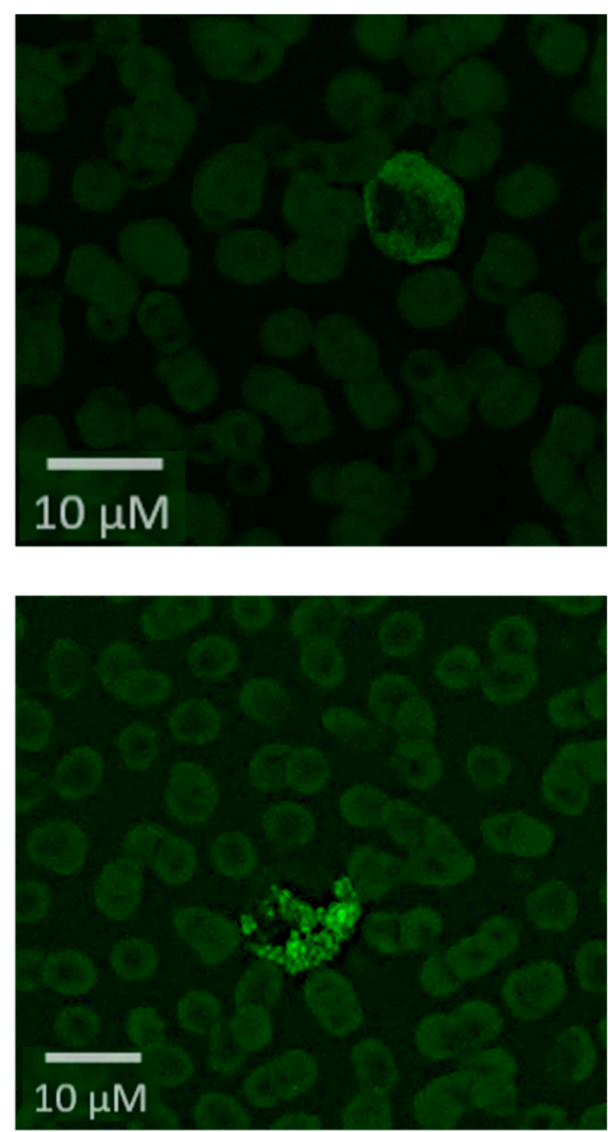

Figure 1. HIF-1 $\alpha$ protein visualization. Fluorescence microscopy from peripheral blood smears of 2 randomly chosen individuals at baseline conditions (Normoxia in Munich, $520 \mathrm{~m}$ a.s.l, upper part) and hypobaric hypoxia (after $24 \mathrm{~h}$ at Little Matterhorn summit, $3.883 \mathrm{~m}$ a.s.l., lower part) conditions using a primary mouse antihuman HIF- $1 \alpha$ antibody. Erythrocytes can be identified due to their homogenous size (approximately $8 \mu \mathrm{m}$ ), central concavity, and typical non-fluorescent background staining pattern. All other cells with a size of $8-12 \mu \mathrm{m}$ can be categorized as HIF-1 $\alpha$ positive (entirely fluorescent cells), intermediate (partly fluorescent cells), or negative (nonfluorescent cells).

\section{2. $I L-1 \beta$}

First, we analyzed the mRNA expression of IL-1 $\beta$, a master cytokine of the inflammatory response, linking hypoxic and inflammatory pathways.

In vitro, compared to unstimulated controls $(0.27(0.14-0.47))$, mRNA expression of IL-1 $\beta$ was increased both following isolated inflammatory stimulation with CD3/C28 $(0.49(0.31-0.84) ; p=0.006)$ or profound hypoxia $\left(5 \% \mathrm{O}_{2}: 0.39(0.24-0.88) ; p=0.004\right.$, Figure $2 \mathrm{~A}$ for $24 \mathrm{~h}$. 
A

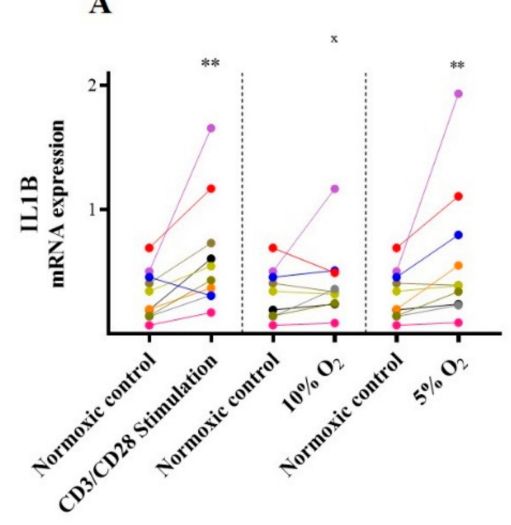

B

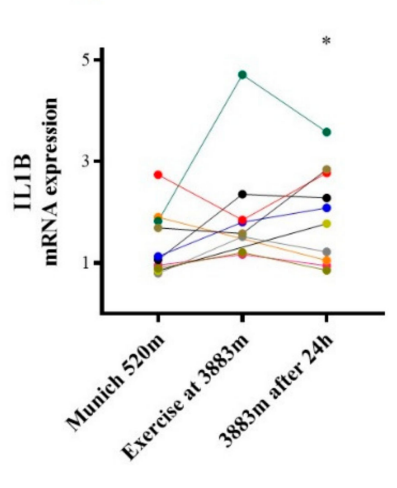

C

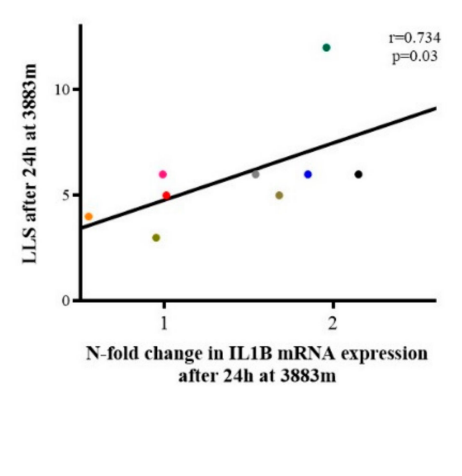

Figure 2. IL-1 $\beta$. IL-1 $\beta$ mRNA expression (A) in vitro following inflammatory and hypoxic incubation, and (B) in vivo at different timepoints. (C) Association between LLS and IL-1 $\beta$ mRNA expression (n-fold change) at $3883 \mathrm{~m}$ a.s.l. after $24 \mathrm{~h}$. ${ }^{*} p \leq 0.05$ and ${ }^{* *} p<0.01$ vs. baseline (Munich $520 \mathrm{~m}$ or normoxic control in vitro), ${ }^{\mathrm{x}} p \leq 0.05$ vs. CD3/CD28-stimulation, $p \leq 0.05$ vs. prior time point in vivo (n.s.). IL-1 $\beta=$ Interleukin $1 \beta$. LLS = Lake Louise Score.

Similarly, IL-1 $\beta$ mRNA expression increased after $24 \mathrm{~h}$ at hypobaric hypoxia on the mountain $(1.94 \pm 0.93$ vs. Munich $520 \mathrm{~m}: 1.38 \pm 0.63, p=0.05$, Figure $2 \mathrm{~B})$. After $24 \mathrm{~h}$ at $3883 \mathrm{~m}$, there was a significant association between IL-1 $\beta$ mRNA expression and the individuals' LLS at this time point $(r=0.734, p=0.03$; Figure 2C).

\subsection{Chemokine Receptors}

\subsubsection{CXCR-4/SDF-1}

In a next step, we analyzed C-X-C Chemokine receptor type 4 (CXCR-4), a lymphocyte chemoattractant receptor, and its ligand stromal cell-derived factor 1 (SDF-1), which had been reported to be altered by combined inflammatory stress and hypoxia.

In vitro CXCR-4 mRNA expression did not change following isolated inflammatory or hypoxic stimulation (all $p=$ n.s.; Figure 3A). Similar results were seen for supernatant concentration of SDF-1 protein, the ligand of CXCR-4 (all $p=$ n.s.).

A

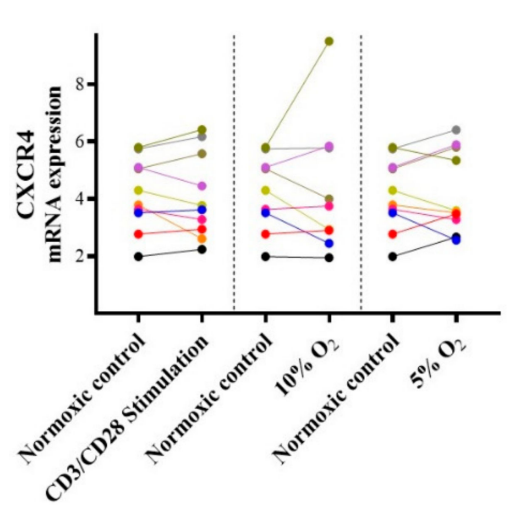

B

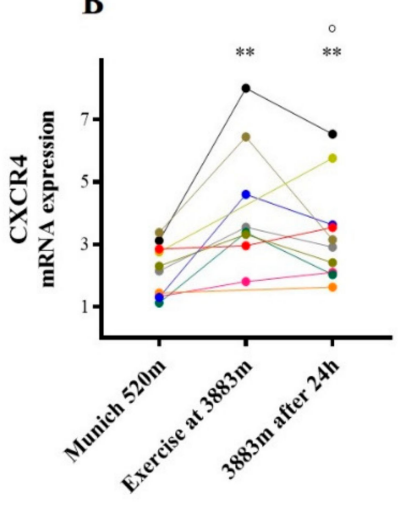

C

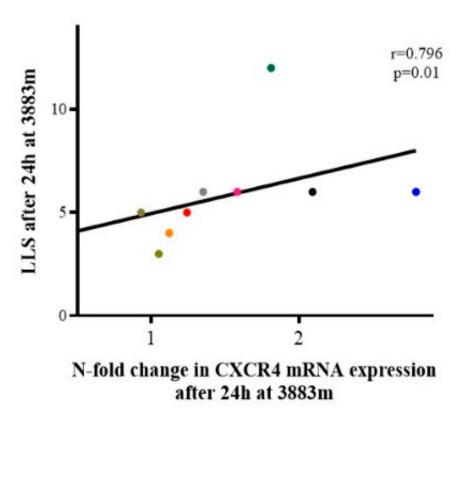

Figure 3. CXCR-4. CXCR-4 mRNA expression (A) in vitro following inflammatory and hypoxic incubation, and (B) in vivo at different timepoints. (C) Association between LLS and CXCR4 mRNA expression (n-fold change) at $3883 \mathrm{~m}$ after $24 \mathrm{~h}$. ${ }^{* *} p<0.01 \mathrm{vs}$. baseline (Munich $520 \mathrm{~m}$ a.s.l. or normoxic control in vitro), ${ }^{\circ} p \leq 0.05$ vs. prior time point in vivo. CXCR4=C-X-C chemokine receptor type 4.

In contrast, in vivo following combined hypoxic and exercise stress CXCR-4 mRNA expression increased (3.46 (3.05-5.98) vs. $2.23(1.31-2.92) ; p=0.008)$ and remained elevated after $24 \mathrm{~h}$ on the 
mountain (3.03 (2.08-4.16); $p=0.01$; Figure 3B. Furthermore, CXCR-4 mRNA expression was associated with increased LLS after $24 \mathrm{~h}$ on the mountain $(r=0.796, p=0.01$, Figure 3C), whereas plasma concentration of the CXCR-4 ligand SDF-1 was unaltered after exercise at high altitude and even slightly declined after $24 \mathrm{~h}$ under hypoxia (all $p=$ n.s.).

\subsubsection{CCR-2/MCP-1 and VEGF-A}

In a next step, we analyzed the monocyte C-C Chemokine receptor type 2 (CCR-2), its ligand monocyte chemotactic protein 1 (MCP-1), and the target gene VEGF-A.

In vitro, CCR-2 mRNA expression increased following hypoxic incubation at $10 \% \mathrm{O}_{2}(3.40 \pm 2.60$ vs. $2.67 \pm 2.00, p=0.04)$ and $5 \% \mathrm{O}_{2}(4.16 \pm 2.89, p=0.005)$, but not following inflammatory stimulation with CD3/CD28 ( $p=$ n.s.; Figure $4 \mathrm{~A})$.
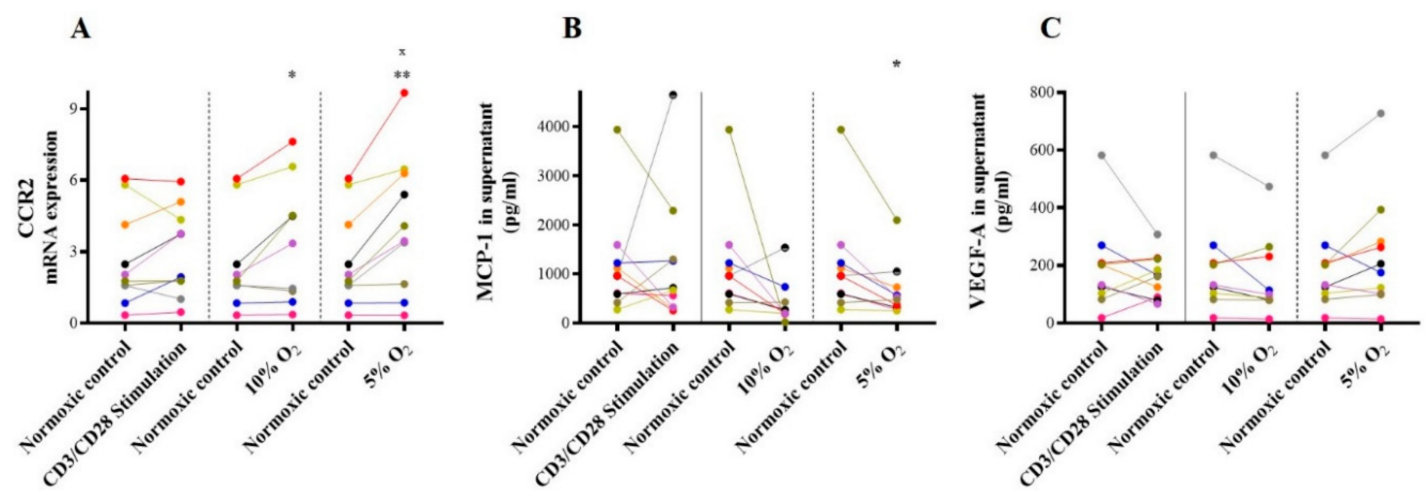

Figure 4. CCR-2, MCP-1, and VEGF-A in vitro. In vitro mRNA expression of (A) CCR-2 and (B) MCP-1, as well as (C) VEGF-A supernatant concentration, both following inflammatory and hypoxic incubation; ${ }^{*} p \leq 0.05,{ }^{* *} p<0.01$, and ${ }^{\mathrm{x}} p \leq 0.05$ vs. CD3/CD28-stimulation, CCR-2=C-C chemokine receptor type 2.

MCP-1 = Monocyte chemotactic protein 1. VEGF-A = vascular endothelial growth factor A.

In contrast, MCP-1, the ligand of CCR-2, was unchanged following incubation with CD3/CD28 ( $p=$ n.s.) or $10 \% \mathrm{O}_{2}(p=$ n.s.), and MCP-1 even decreased following profound hypoxic stimulation with $5 \% \mathrm{O}_{2}$ (501.3 (309.7-809.4) pg/mL vs. 965.9 (549.2-1318.0) pg/mL, $p=0.02$, Figure 4B). In a next step, we analyzed the MCP-1 target gene VEGF-A in the cell culture supernatant. With MCP-1 concentration being not induced, supernatant concentration of the MCP-1 target gene VEGF-A was unaltered as well both following hypoxic and CD3/CD28 incubation (all $p=$ n.s., Figure $4 \mathrm{C}$ ).

In vivo, both CCR-2 mRNA expression (3.28 \pm 0.72 vs. $2.93 \pm 0.83, p=0.03$, Figure $5 \mathrm{~A}$ ) and MCP-1 plasma concentration $(50.10(26.73 \pm 79.64) \mathrm{pg} / \mathrm{mL}$ vs. $<4.20 \mathrm{pg} / \mathrm{mL}, p<0.001$, Figure $5 \mathrm{~B})$ were increased after exercise under hypoxia compared to baseline. CCR-2 mRNA expression remained elevated after $24 \mathrm{~h}$ on the mountain $(4.18 \pm 0.95 ; p=0.01$; Figure $5 \mathrm{~A})$, whereas plasma concentration of its ligand MCP-1 already had returned to baseline after $24 \mathrm{~h}(p=$ n.s., Figure 5B). Notably, plasma concentrations of MCP-1 target gene VEGF-A were 5 to 10 -fold greater than other subjects at baseline, and further increased as early as at arrival at $3883 \mathrm{~m}$ a.s.l, (54.74 (32.25-84.79) pg/mL vs. $22.60(15.48-36.81) \mathrm{pg} / \mathrm{mL}$, $p=0.005$, Figure 5C), kept increased after exercise $(42.70(21.75-92.54) \mathrm{pg} / \mathrm{mL}, p=0.01)$ and returned to baseline after $24 \mathrm{~h}$ on the mountain.

Of note, already at baseline in two individuals VEGF-A plasma concentrations was 10-fold increased, and further increased under hypoxia. Importantly, a subanalysis excluding these volunteers did not alter the observed increase. 

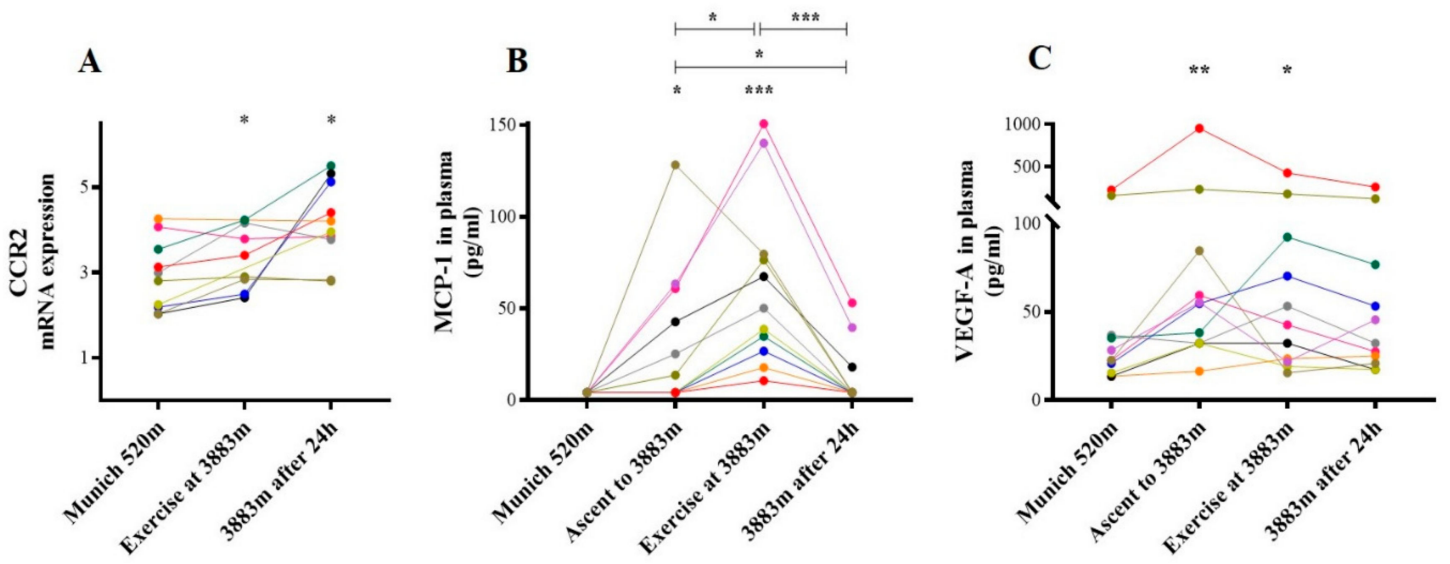

Figure 5. CCR-2, MCP-1, and VEGF-A in vivo. In vivo mRNA expression of (A) CCR-2 and (B) MCP-1, as well as (C) VEGF-A plasma concentration at time points analyzed; ${ }^{*} p \leq 0.05,{ }^{* *} p<0.01$, and ${ }^{* * *} p<0.001$ vs. baseline (Munich $520 \mathrm{~m}$ a.s.l.). CCR-2=C-C chemokine receptor type 2. MCP-1 = Monocyte chemotactic protein 1 . VEGF-A = Vascular epithelial growth factor A.

\subsection{Proinflammatory Cytokines}

Finally, we analyzed plasma concentrations of further pro- and anti-inflammatory cytokines.

\subsubsection{Interleukin-3}

In vitro, IL-3 plasma concentration remained unchanged both following CD3/CD28 and hypoxic incubation (all $p=$ n.s.).

In contrast, in vivo IL-3 plasma concentration (63.31 (25.45-119.10) $\mathrm{pg} / \mathrm{mL})$ increased as early as at arrival at $3883 \mathrm{~m}$ a.s.l. (122.10 (75.77-253.80 pg/mL, $p<0.001)$ kept elevated after exercise (152.9 (81.99-198.80) pg/mL, $p=0.05)$ and returned to baseline after $24 \mathrm{~h}$ on the mountain (94.38 (50.79-168.20) $\mathrm{pg} / \mathrm{mL} ; p=$ n.s.)

\subsubsection{Interleukin-6}

In vitro IL-6 supernatant concentration increased highly significantly following stimulation with CD3/CD28 (134.10 (112.3-150.00) pg/mL, $p=0.002)$, but was unaltered following hypoxic incubation with $10 \%$ and $5 \% \mathrm{O}_{2}$, respectively (all $p=$ n.s.).

In vivo IL-6 plasma concentration was below detection threshold at all timepoints (all $p=n . s$; detection threshold $7.45 \mathrm{pg} / \mathrm{mL}$ ).

\subsubsection{TNF- $\alpha$}

In vitro, TNF- $\alpha$ supernatant concentrations were below detection threshold following inflammatory and hypoxic incubations (all $p=$ n.s; detection threshold $8.47 \mathrm{pg} \cdot \mathrm{mL}^{-1}$ ).

Similarly, in vivo TNF- $\alpha$ plasma concentrations were below detection threshold, too (all $p=n . s$ ).

\subsection{Anti-Inflammatory Cytokines}

\subsubsection{IL-10}

IL-10 supernatant concentrations from in vitro PBMC cultures increased following CD3/CD28 stimulation $(13.81 \pm 5.34 \mathrm{pg} / \mathrm{mL}$ vs. $7.25 \pm 5.71 \mathrm{pg} / \mathrm{mL})$, but not following hypoxic incubation (all $p=$ n.s.).

In vivo, IL-10 plasma concentration (baseline $<2.12 \mathrm{pg} / \mathrm{mL}$ ) was greatly increased as early as at arrival at $3883 \mathrm{~m}$ a.s.l. (2.61 (2.12-5.69) pg/mL, $p=0.03)$, kept increasing after exercise (3.46 (2.12-6.28) $\mathrm{pg} / \mathrm{mL}, p=0.02)$, then returned to baseline after $24 \mathrm{~h}$ on the mountain $(p=\mathrm{n.s}$.). Of interest, after $24 \mathrm{~h}$ 
the four individuals with highest LLS showed a trend towards lower IL-10 plasma concentrations (lowest LLS 4.02 (2.18-7.13) pg/mL vs. highest LLS $1.80(0.91-2.48) \mathrm{pg} / \mathrm{mL}, p=0.14$ ).

\subsubsection{IL-1RA}

In vitro, IL-1RA (Figure 6A) supernatant concentrations increased following CD3/CD28 stimulation $(1499 \pm 2225 \mathrm{pg} / \mathrm{mL}$ vs. $4842 \pm 3063 \mathrm{pg} / \mathrm{mL} p<0.01)$, but not under hypoxia (all $p=$ n.s.).
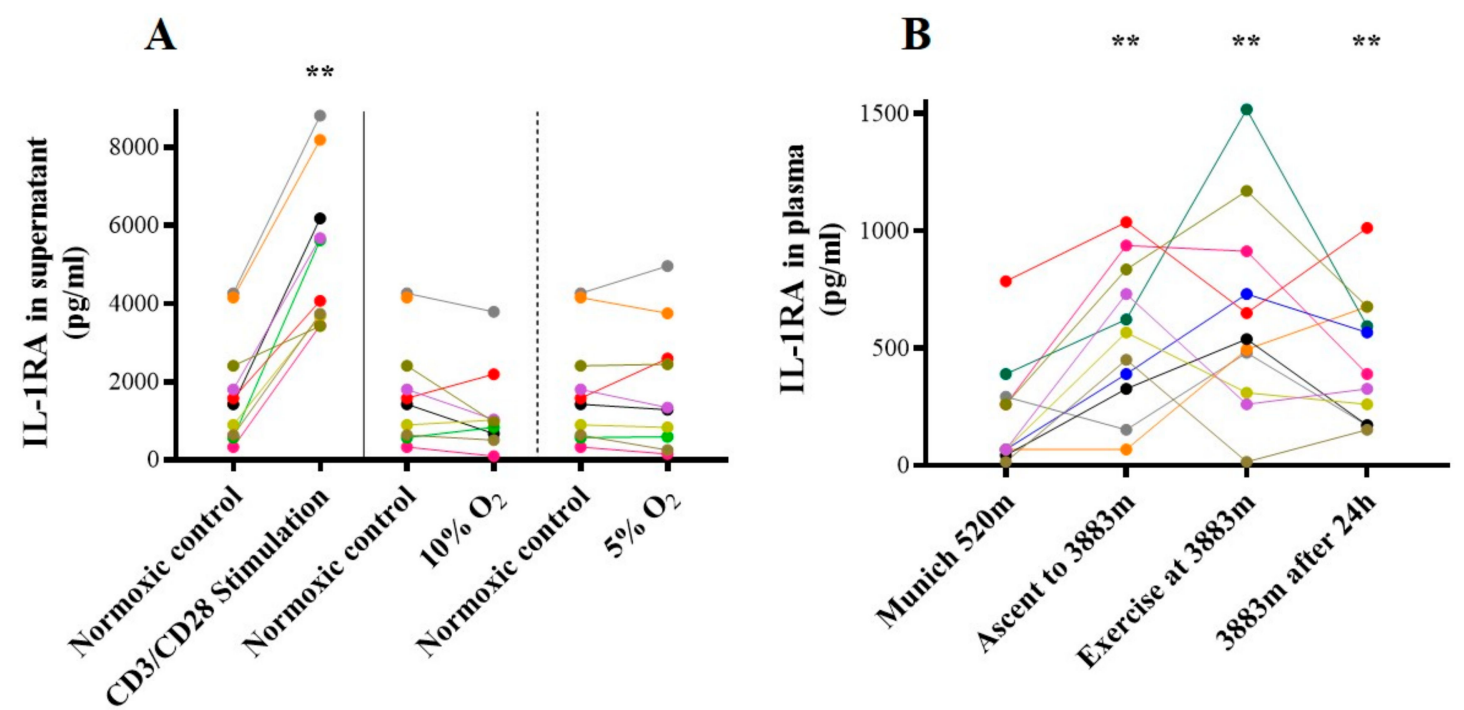

Figure 6. IL-1RA. Concentration of IL-1RA (A) in vitro in cell culture supernatant following inflammatory and hypoxic incubation, and (B) in vivo in plasma at different timepoints. ${ }^{* *} p<0.01$ vs. baseline (Munich $520 \mathrm{~m}$ a.s.l. or normoxic control in vitro), IL-1RA= Interleukin-1 receptor antagonist.

In contrast, in vivo, IL-1RA plasma concentration was highly increased at arrival at $3883 \mathrm{~m}$ compared to baseline $(556.80 \pm 313.60 \mathrm{pg} / \mathrm{mL}$ vs. $211.80 \pm 228.40 \mathrm{pg} / \mathrm{mL}, p=0.001)$, kept increased after exercise $(644.30 \pm 428.20 \mathrm{pg} / \mathrm{mL}, p=0.004)$, and after $24 \mathrm{~h}$ on the mountain $(455.10 \pm 274,40 \mathrm{pg} / \mathrm{mL}$, $p=0.002$; Figure 6B). After $24 \mathrm{~h}$ at $3883 \mathrm{~m}$, the four individuals with lowest LLS showed doubled IL1-RA plasma concentrations compared to those with highest LLS, however the difference did not reach statistical significance (lowest LLS $630.5 \pm 177.8 \mathrm{pg} / \mathrm{mL}$ vs. highest LLS $332.3 \pm 101.7 \mathrm{pg} / \mathrm{mL}$, $p=0.20)$.

\section{Discussion}

In this prospective observational trial, we have shown that the hypoxic-inflammatory response is differentially regulated following hypoxic or inflammatory stimulation in vitro compared to the in vivo response during an expedition in acute hypobaric hypoxia. Though, the combined hypoxic and exercise stimulus in vivo had a different and more pronounced effect on gene regulation and cytokine release than isolated hypoxic or inflammatory stimulation of PBMCs from these volunteers in vitro. Of note, both pro-inflammatory IL- $1 \beta$ and chemoattractant receptor CXCR-4 mRNA expression changes were associated with increased LLS and symptoms of AMS in vivo.

First, we performed in vitro experiments with PBMCs from healthy non-acclimatized volunteers using isolated inflammatory (CD3/CD28) or hypoxic $\left(10 \% \mathrm{O}_{2 / 5} \% \mathrm{O}_{2}\right)$ stimuli. Here, an isolated inflammatory stimulus increased the mRNA expression of IL-1 $\beta$, supernatant protein concentrations of its antagonist IL-1RA, of pro-inflammatory IL-6 and anti-inflammatory IL-10. This is of interest, as even a slight increase in IL- $1 \beta$ is sufficient to cause fever, activate neutrophils, or to induce a proinflammatory response in terms of i.e., IL-6 release [35]. More importantly, recent publications suggest that in addition to pro-inflammatory mechanisms, IL-1 $\beta$ is responsible for the resolution of inflammation and the reprogramming of monocytes towards an immunosuppressive phenotype [36]. 
In this regard, our results show that CD3/CD28 induced IL- $1 \beta$ mRNA expression and the release of both pro- and anti-inflammatory cytokines in vitro, whereas hypoxia did not increase supernatant concentrations of aforementioned cytokines.

In vivo, we obtained similar results when we analyzed blood samples withdrawn from the same individuals after $24 \mathrm{~h}$ under hypobaric hypoxia. Here, IL-1 $\beta$ mRNA expression was increased and this was associated with an increased LLS. Thus, one might emphasize that alteration in serum cytokine concentrations under hypoxia might be associated with clinical symptoms of AMS: this is in accordance with previous studies showing that IL- $1 \beta$, IL-6, and TNF- $\alpha$ were increased in AMS patients, or that an inhibition of anti-inflammatory IL-10 was associated with AMS in a genome wide study $[31,37,38]$. In contrast, other studies did not find an association between circulating cytokines like IL-3, IL-6, or IL-10, exercise and AMS [38-40].

In conclusion, contradictory studies had been published to this topic, which suggests that further pathways are involved in the humans' response to acute hypobaric hypoxia and the development of AMS.

In this regard, in a next step, we analyzed chemoattractant receptor CXCR-4, and its ligand SDF-1. CXCR-4 plays an important role in target-oriented migration of stem and immune cells towards the site of infection, while recent studies even propose an association with neuroinflammation [32,33,41]. This is of particular interest as CXCR-4 and its ligand SDF-1 are the key elements regulating the entrance of lymphocytes to the central nervous system [42]. Now, we have shown an association between CXCR-4 mRNA expression and increased LLS after $24 \mathrm{~h}$ at hypobaric hypoxia. Further studies are needed to analyze whether the CXCR-4/SDF-1 signaling pathway is induced in AMS and HACE and whether this is associated with increased passover of lymphocytes through the blood-brain barrier [34].

In addition to CXCR-4 and its ligand SDF-1, another monocyte chemoattractant protein CCR-2 and its ligand MCP-1 are involved in neuroinflammatory diseases as well. This is highly interesting as it is known that the CCR-2/MCP-1 axis is activated by hypoxia through the HIF-1 signaling pathway [43]. Here, we were able to show that CCR-2 is induced by hypoxia but not inflammatory stimulation in vitro and increases in volunteers exposed to hypobaric hypoxia in vivo. Furthermore, its ligand MCP-1 was highly induced in our volunteers as early as at arrival in high altitude. This is interesting as the CCR-2/MCP-1 signaling pathway is induced in neurological disorders like epilepsia, and associated with neuroinflammation [44]. Furthermore, CCR-2 stimulation activates STAT3 (signal transducer and activator of transcription 3) phosphorylation and further increases IL-1 $\beta$ release itself, which might perpetuate inflammatory pathways aggravating AMS under persistent hypoxia [44]. Supernatant concentration of the HIF-target gene VEGF-A was unaltered in vitro after $24 \mathrm{~h}$ of $10 \%$ and $5 \% \mathrm{O}_{2}$ hypoxic incubation. This is in accordance with a recent publication showing that VEGF-A increased as late as after $48 \mathrm{~h}$ when extreme $\left(1 \% \mathrm{O}_{2}\right)$ hypoxia was applied $[45,46]$. In contrast, in humans, in vivo moderate hypoxia, especially when combined with exercise, is capable of increasing VEGF-A protein $[40,47]$.

Regulation of hypoxia-induced pathways is highly complex, thus additionally to the targets analyzed in our trial, different proteins are of particular importance. In this regard, especially vasodilatator nitric oxide is of special interest, as its effects are enhanced under hypoxia as has already been shown in animal and human studies [48].

HIF- $1 \alpha$ itself plays an important role in the modulation of $\mathrm{CD} 4^{+} \mathrm{T}$ cell functions under hypoxic conditions in colon cancer mice cell cultures and can decrease T cell immunity [49]. This HIF-1 $\alpha$-related immunosuppression can inhibit anti-tumor effects and give strong evidence for supplemental oxygen application in cancer therapies [50]. The hypoxia-HIF-related inhibition of innate immune cells may also affect the inflammatory response to hypobaric and normobaric hypoxia in our trial.

\section{Materials and Methods}

After approval by the Ethics Committee of the University of Munich, Germany (19th August 2016; project no. 350-16), healthy volunteers were enrolled in this prospective observational trial. 
The trial consisted of two parts: First, in vitro, we analyzed the effect of hypoxic and inflammatory stimuli on peripheral blood mononuclear cells (PBMCs) from healthy volunteers. Second, we performed a mountain expedition in which the aforementioned volunteers were acutely exposed to hypobaric hypoxia.

For in vitro experiments, whole blood samples were taken at our molecular laboratory in Munich, Germany (520 m a.s.l.) and immediately processed as depicted below. Subsequently, healthy volunteers took part in an expedition from Munich to Zermatt and blood was withdrawn and stored at three different time points as depicted in Figure 1. Detailed study protocol and results of hemodynamic changes, cerebral oxygenation, and cognitive function were published previously [24].

\subsection{Volunteers Characteristics}

Following written informed consent, healthy female $(n=5)$ and male $(n=6)$ individuals were included in this study. All subjects were in good physical and mental condition, trained, and without any comorbidities or medication. Volunteer characteristics are depicted in Table 1. Volunteers aged 18 years or older were eligible for study inclusion. Exclusion criteria included mental disorders, infection, immunological disorders, pregnancy, any kind of preexisting cardiopulmonary disease, and exposition to altitudes higher than $2000 \mathrm{~m}$ a.s.l. within two months before the study. During the study, one volunteer met exclusion criteria and thus was excluded from further analyses. After $24 \mathrm{~h}$ in hypobaric hypoxia, 6 of 11 subjects $(54.6 \%$ ) developed AMS (moderate or severe headache in combination with LLS point sum $\geq 3$ ). Detailed volunteer characteristics are displayed in Table 1.

Table 1. Volunteer characteristics.

\begin{tabular}{cc}
\hline Volunteer Characteristics & $N=\mathbf{1 1}$ \\
\hline Gender, female/male (numbers; \%) & $5 / 6(45 / 55)$ \\
Age (Years; MV $\pm \mathrm{SD})$ & $36.4 \pm 7$ \\
Height $(\mathrm{cm} ; \mathrm{MV} \pm \mathrm{SD})$ & $178 \pm 6$ \\
Bodyweight $(\mathrm{kg} ; \mathrm{MV} \pm \mathrm{SD})$ & $72.7 \pm 10$ \\
Body Mass Index (kg/m $\left.{ }^{2} ; \mathrm{MV} \pm \mathrm{SD}\right)$ & $22.7 \pm 2$ \\
Heart rate $\left(\mathrm{min}^{-1} ; \mathrm{MV} \pm \mathrm{SD}\right)$ & $61 \pm 9$ \\
Peripheral oxygen saturation & $97 \pm 1$ \\
$\left(\mathrm{SpO}_{2 ;} \%\right.$; MV $\left.\pm \mathrm{SD}\right)$ & \\
\hline
\end{tabular}

\subsection{In Vitro Experiments}

\subsubsection{PBMC Isolation}

For in vitro experiments, heparinized venous blood samples from 10 of the 11 volunteers were collected and PBMCs were separated using Leucosep ${ }^{\mathrm{TM}}$-Tubes (Greiner Bio-One GmbH, Frickenhausen, Germany) and Histopaque ${ }^{\circledR}$ density gradient centrifugation (Sigma Aldrich, Taufkirchen, Germany) [51]. In 6-well plates, $3.0 \times 10^{6}$ cells per well were suspended in $2 \mathrm{~mL}$ RPMI-medium with $10 \%$ fetal calf serum, $1 \%$ L-Glutamin (Biochrom AG, Berlin, Germany), and 1\% HEPES (Sigma Aldrich, Taufkirchen, Germany) for $24 \mathrm{~h}$ at $37^{\circ} \mathrm{C}$ with $5 \% \mathrm{CO}_{2}$.

\subsubsection{Cell CULTURE Experiments}

Cells were cultured at four different conditions for $24 \mathrm{~h}:$ a) "normoxic control": normoxia with $21 \% \mathrm{O}_{2}, 5 \% \mathrm{CO}_{2}, 37^{\circ} \mathrm{C} ; \mathrm{b}$ ) “CD3/CD28": $21 \% \mathrm{O}_{2}, 5 \% \mathrm{CO}_{2}, 37^{\circ} \mathrm{C}$ with $1 \mathrm{~mL}$ of supernatant from PBMCs of the same subject previously stimulated with Dynabeads ${ }^{\mathrm{TM}}$ Human T-Activator CD3/CD28 (Gibco, Thermo Fisher Scientific; Vilnius, Lithuania) (see Supplementary Materials); c) " $10 \% \mathrm{O}_{2}$ ": hypoxia with $10 \% \mathrm{O}_{2}, 40 \mathrm{mmHg} \mathrm{CO}, 37^{\circ} \mathrm{C}$ or d) " $5 \% \mathrm{O}_{2}$ ": hypoxia with $5 \% \mathrm{O}_{2}, 40 \mathrm{mmHg} \mathrm{CO}_{2}, 37^{\circ} \mathrm{C}$, carried out in modular incubator chambers (Billups-Rothenberg Inc, Del Mar, USA). Due to a broken seal 
in the hypoxic chamber of volunteer 3, PBMC analyses under $10 \% \mathrm{O}_{2}$ could only be carried out in 9 volunteers. Hypoxia with $10 \% \mathrm{O}_{2}$ was chosen to expose PBMCs to a similar oxygen level as at $3883 \mathrm{~m}$ a.s.l. in the in vivo trial. This was calculated using the alveolar gas equation, originally described by Fenn et al., and the international barometric altitude formula.

Alveolar gas equation [52]:

$$
\mathrm{pAO}_{2}=\left(\mathrm{p}_{\mathrm{atm}}-\mathrm{p}_{\mathrm{H} 20}\right) \times \mathrm{FiO}_{2}-\left(\mathrm{p}_{\mathrm{A}} \mathrm{CO}_{2} / \mathrm{RQ}\right)
$$

International barometric altitude formula [53]:

$$
\mathrm{p}_{\mathrm{atm}}=1013.25 \mathrm{hPa} \times[1-(6.5 \times \text { altitude } / 288150 \mathrm{~m})]^{5.255}
$$

$\mathrm{pAO}_{2}=$ alveolar partial $\mathrm{O}_{2}$ pressure; $\mathrm{p}_{\mathrm{atm}}=$ atmospheric pressure; $\mathrm{p}_{\mathrm{H} 20}=$ water vapor pressure at $37 \%$ and full saturation $\mathrm{p}_{\mathrm{H} 20}=47 \mathrm{mmHg} ; \mathrm{FiO}_{2}=$ inspiratory $\mathrm{O}_{2}$-concentration; $\mathrm{p}_{\mathrm{A}} \mathrm{CO}_{2}=$ alveolar partial $\mathrm{CO}_{2}$-pressure (normal $\mathrm{p}_{\mathrm{A}} \mathrm{CO}_{2}=40 \mathrm{mmHg}$ ); $\mathrm{RQ}=$ respiratory quotient (at normal nutrition $\mathrm{RQ}=0.8$.

Calculation of oxygen level for PBMCs:

$\mathrm{p}_{\mathrm{atm}}=625.9 \mathrm{hPa}=469 \mathrm{mmHg}$

Sea level: $1013 \mathrm{hPa}, \mathrm{FiO}_{2}=0.21$

Little Matterhorn summit (3883 m a.s.l.): $\mathrm{FiO}_{2}=625.9 \mathrm{hPa} / 1013 \mathrm{hPa} \times 0.21=0.13$.

Alveolar gas equation:

$$
\mathrm{pAO}_{2}=(469 \mathrm{mmHg}-47 \mathrm{mmHg}) \times 0.13-(40 / 0.8)=4.86 \mathrm{mmHg}
$$

Proportion of $\mathrm{p}_{\mathrm{atm}}: 4.86 \mathrm{mmHg} / 469 \mathrm{mmHg}=0.01036=10.36 \%$.

Total mRNA was isolated using mirVana ${ }^{\mathrm{TM}}$ miRNA Isolation Kit (Invitrogen, Thermo Fisher Scientific Baltics UAB; Vilnius, Lithuania) and TURBO DNA-free ${ }^{\mathrm{TM}}$ Kit $^{(A m b i o n}{ }^{\circledR}$, Life Technologies $^{\mathrm{TM}}$, Carlsbad, USA). NanoDrop 1000 spectrophotometer (Peqlab Biotechnologie GmbH, Erlangen, Germany) was used to measure RNA quantity and purity. mRNA was stored by $-80{ }^{\circ} \mathrm{C}$ till further processing and analysis. Furthermore, supernatant was stored by $-80^{\circ} \mathrm{C}$ for further analyses.

\subsection{Expedition Trial}

During the expedition trial, blood withdrawal was performed at four different time points (Figure 7). In detail, after initial baseline measurement in the morning in Munich at $520 \mathrm{~m}$ a.s.l. (Munich $520 \mathrm{~m}$ ) all individuals were transferred to Zermatt, Switzerland, by car. In the next morning, ascent to the Little Matterhorn summit at $3883 \mathrm{~m}$ a.s.l. was done by funicular (duration $45 \mathrm{~min}$ ), followed by further measurements immediately after ascent to $3883 \mathrm{~m}$ ( $24 \mathrm{~h}$ after baseline measurement). After this, all subjects performed endurance exercise by descending and re-ascending a ski slope between 3883 and $3500 \mathrm{~m}$ a.s.l. over $120 \mathrm{~min}$ [24]. Immediately after physical exercise, measurements were performed in an expedition tent (Keron 4 GT, Hilleberg AB, Frösön, Sweden) on the glacier (Exercise at $3883 \mathrm{~m}$ ) at minus $11{ }^{\circ} \mathrm{C}$. After spending one night at $3883 \mathrm{~m}$ a.s.l. and $24 \mathrm{~h}$ of hypoxic exposure, blood was taken a last time (3883 $\mathrm{m}$ after $24 \mathrm{~h}$ ). Except for the third time point (Exercise at $3883 \mathrm{~m}$ ), measurements were carried out in a protected environment (University Hospital Munich and Lodge Matterhorn Glacier Paradise). Nine mL blood was collected in EDTA-plasma tubes (Sarstedt, Nuernbrecht, Germany) at all timepoints, centrifuged at $3000 \mathrm{rpm}$ for $10 \mathrm{~min}$ and plasma was immediately stored at $-20^{\circ} \mathrm{C}$. After arrival in Munich, samples were transferred to a $-80{ }^{\circ} \mathrm{C}$ freezer. Furthermore, for mRNA analyses $9 \mathrm{~mL}$ blood was withdrawn in PAXgene ${ }^{\circledR}$ Blood RNA Tubes (PreAnalytiX ${ }^{\circledR}$, Hombrechtikon, Switzerland), handled following the manufacturers protocol and stored at $-20^{\circ} \mathrm{C}$. mRNA was extracted using PAXgene ${ }^{\circledR}$ Blood miRNA Kit (PreAnalytiX ${ }^{\circledR}$, Hombrechtikon, Switzerland) according to the manufacturer's instructions and as described above, RNA quantity and purity was measured with a 
NanoDrop-1000 spectrophotometer (Peqlab Biotechnologie, Erlangen, Germany). If the amount of RNA processed was less than $8 \mathrm{ng} / \mu \mathrm{L}$, an analysis could not be carried out. mRNA was stored at $-80^{\circ} \mathrm{C}$ until further processing.

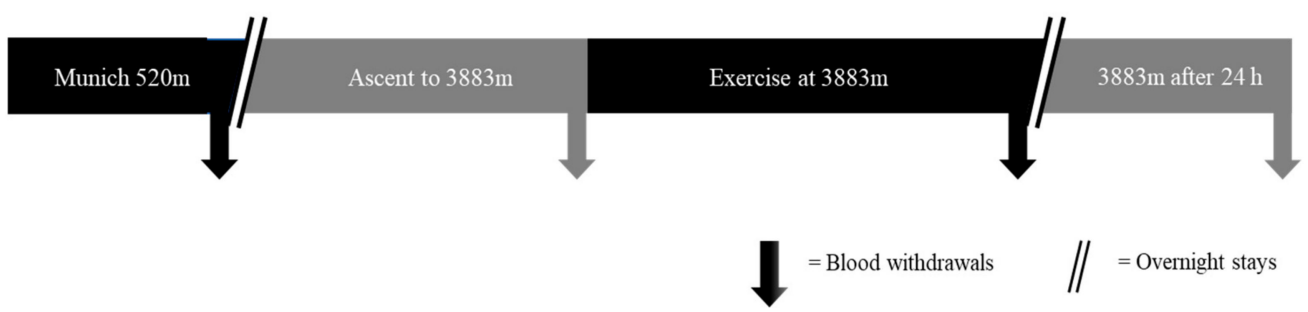

Figure 7. Study protocol for expedition trial. Blood withdrawal and clinical analyses were performed at baseline (Munich $520 \mathrm{~m}$ a.s.l.), upon arrival at $3883 \mathrm{~m}$ a.s.l. (Ascent to $3883 \mathrm{~m}$ ), following $90 \mathrm{~min}$ of endurance training (Exercise at $3883 \mathrm{~m}$ ) and after $24 \mathrm{~h}$ at $3883 \mathrm{~m}$ a.s.l (3883 $\mathrm{m}$ after $24 \mathrm{~h}$ ).

\subsection{Molecular Analyses}

\subsubsection{HIF-Visualization}

Isolation of HIF protein from whole blood samples is almost impossible due to short halftime of HIF proteins. Thus, we recently established the visualization of HIF protein using blood smears as published previously [6]. In detail, blood smears were prepared, and immediately frozen within $5 \mathrm{~min}$ after blood withdrawal. For immunofluorescence staining, blood smears were thawed for $10 \mathrm{~min}$ at room temperature and fixed with ice cold methanol/acetone (1:1) for $10 \mathrm{~min}$ at $-20^{\circ} \mathrm{C}$. Afterward, immunofluorescence staining was performed using a primary mouse antihuman HIF-1 $\alpha$ antibody (Transduction Laboratories), followed by an IgG Alexa-Flour 488 coupled goat anti-mouse antibody (Molecular Probes, order No. A11001, Eugene, OR, USA), as described previously [6].

Fluorescence microscopy was performed on an Olympus BX51 Upright (40× Lens (400× magnification); manual exposure 348 ms; FITC filter; program: cellSens Dimension) using the NIS-Elements F.30.0 imaging software (Laboratory Imaging, Prague, Czech Republic). All slides were analyzed using a standardized procedure. Erythrocytes, which account for the major portion of cells in blood smears, were easily identified due to their homogenous size (approximately $8 \mu \mathrm{m}$ ), central concavity, and typical non-fluorescent background staining pattern. All other cells with a size of 8-12 $\mu \mathrm{m}$ were analyzed, and categorized as HIF- $1 \alpha$ positive (entirely fluorescent cells), intermediate (partly fluorescent cells), or negative (nonfluorescent cells) using the image software Image J 1.43r (National Institute of Health, Bethesda, MD, USA).

\subsubsection{Real-Time PCR (qPCR)}

cDNA was synthesized using SuperScript ${ }^{\circledR}$ III Reverse Transcriptase (InvitrogenTM, Carlsbad, USA), oligo-dT and random hexamer primers (Qiagen $\mathrm{GmbH}$, Hilden, Germany), and Deoxynucleoside Triphosphate Set (dNTPs) (Roche Diagnostics, Mannheim, Germany).

Real-time PCR (qPCR) was performed in duplicates on a LightCycler 480 (Roche Diagnostics, Mannheim, Germany) with FastStart Essential DNA Probes Master, Real Time Ready Single Assays (Roche Diagnostics, Mannheim, Germany), oligonucleotides (Metabion International, Planegg, Germany), and UPL-Probes (Roche Diagnostics, Mannheim, Germany). mRNA analyses were performed at baseline (Munich $520 \mathrm{~m}$ ); after exercise (Exercise $3883 \mathrm{~m}$ ) and after $24 \mathrm{~h}$ under hypoxia (3883 $\mathrm{m}$ after $24 \mathrm{~h}$ ). Primer sequences and characteristics of probes and single assays are given in Table 2. The calculation of relative mRNA expression against the reference genes TBP (TATA-box binding protein) and SDHA (Succinate dehydrogenase complex, subunit A) was performed using Advanced Relative Quantification with the LightCycler 480 Software (Roche Diagnostics, Mannheim, Germany) as described previously [54]. 
Table 2. Primer sequences, UPL Probes, and Real Time Ready Single Assays used in qPCR.

\begin{tabular}{ll}
\hline Genes & Primer Sequences, UPL Probes and Assays \\
\hline TBP forward & 5' GAACATCATGGATCAGAACAACA 3' \\
TBP reverse & 5' ATAGGGATTCCGGGAGTCAT 3' \\
& UPL Probe Nr. 87 \\
\hline SDHA forward & 5' GAGGCAGGGTTTAATACAGCA 3' $^{\prime}$ \\
SDHA reverse & 5' CCAGTTGTCCTCCTCCATGT 3' $^{\prime}$ \\
& UPL Probe Nr. 132 \\
\hline CCR-2 forward & 5' TGAGACAAGCCACAAGCTGA 3' \\
CCR-2 reverse & 5' TTCTGATAAACCGAGAACGAGAT 3' \\
& UPL Probe Nr. 56 \\
\hline IL-1 $\beta$ forward & 5' GAGGCACAAGGCACAACAG 3' \\
IL-1 $\beta$ reverse & 5' CCATGGCTGCTTCAGACAC 3' \\
\hline CXCR-4 & UPL Probe Nr. 41 \\
\hline VEGF-A & Assay ID 110817 \\
\hline
\end{tabular}

CXCR-4 = C-X-C Chemokine receptor type 4; CCR-2 = C-C Chemokine receptor type 2; IL1 B = Interleukin 1 $\beta$; SDHA = Succinate dehydrogenase complex, subunit A; TBP $=$ TATA-box binding protein; UPL $=$ Universal Probe Library. VEGF-A=Vascular epithelial growth factor A.

\subsubsection{Cytokine Measurements from Plasma and Supernatant}

Cytokine concentrations were assessed from EDTA-plasma and cell culture supernatant using the Procarta multiplex cytokine kit (Affymetrix, Santa Clara, CA, USA) following the manufacturer's protocol as published previously [6,23]. In detail, plasma and supernatant concentrations of proinflammatory cytokines (Interleukin-3 (IL-3), Interleukin-6 (IL-6), tumor necrosis factor $\alpha$ (TNF $\alpha$ ), anti-inflammatory cytokines (Interleukin-1 receptor antagonist (IL-1RA), Interleukin-10 (IL-10)), chemokines (chemokine $\mathrm{C}-\mathrm{C}$ motif ligand 2/monocyte chemotactic protein 1 (CCL-2/MCP-1), C-X-C motif chemokine 12/stromal cell-derived factor 1 (CXCL-12/SDF-1 $\alpha$ ), and vascular endothelial growth factor A (VEGF-A) were measured at all four timepoints [55]. Duplicate determinations were carried out for all measurements. The measurements were evaluated with the $x P$ ONENT ${ }^{\circledR}$ software for Luminex ${ }^{\circledR} 200$ TM Version 3.1.

\subsection{Clinical Analyses}

Acute Mountain Sickness

Symptoms of acute mountain sickness (AMS), consisting of headache, gastrointestinal problems, insomnia, fatigue, and dizziness, were evaluated using a self-reported questionnaire according to the 2016 Lake Louise Score (LLS, 5 items, maximum point sum 15) [12]. The presence of AMS was defined as moderate or severe headache combined with LLS point sum of $\geq 3$.

\subsection{Statistical Analysis}

Shapiro-Wilk test was performed to test for normal distribution of all datasets. Thus, normally distributed data are given as mean and standard deviation whereas non-normally distributed data are given as median with interquartile range. Changes in LLS were analyzed with Wilcoxon matched-pairs signed rank test. For molecular results, paired Student's $t$-test was performed in case of normal distribution, whereas for non-parametric data, Wilcoxon matched-pairs signed rank test was used. Differences between groups were calculated with unpaired $t$-test or Mann-Whitney $U$ test. Correlations were calculated using Spearman's rank correlation coefficients. Every volunteer was marked with individual colors in all figures to facilitate identification. A $p$-value of $\leq 0.05$ was considered statistically 
significant, and all analyzes were performed using PRISM version 7 (GraphPad Software Inc., La Jolla, CA, USA).

\section{Limitations}

Our study has limitations: First, our collective of 11 healthy female and male volunteers can be considered small and the influence of sex hormones has not been studied. However, volunteers were carefully selected, had no exposure to altitudes higher than $2000 \mathrm{~m}$ a.s.l. within two months prior to experiments, and both in vitro and in vivo analyses have been performed using blood samples from the same individuals. Second, in vitro, we analyzed inflammatory and hypoxic stimuli separately. Whereas, during the in vivo expedition trial on the mountain, we analyzed mRNA expression and serum cytokine concentrations from all individuals at different time points, but the study protocol did not allow to differentiate between hypoxia and exercise stress, as all volunteers underwent endurance training on the mountain. Third, on the mountain, we analyzed mRNA expression from whole blood samples and measured cytokine serum concentrations at different time points but did not isolate PBMCs in vitro to analyze ex vivo stimulability of cells exposed to hypoxia in vivo. This would be of interest to compare stimulability of PBMCs isolated in Munich under baseline conditions to hypoxic cells isolated on the mountain. However, it is known that neutrophils, which are missing in PBMCs, can be mobilized from the whole blood in case of inflammation, which is also known as leukocyte adhesion cascade $[56,57]$. These neutrophils are able to upregulate CXCR4 expression, which was also measured in our trial [58]. This could be a possible explanation, why CXCR4 mRNA expression was unchanged in PBMCs in vitro, whereas it was upregulated in whole blood samples in vivo. Furthermore, neutrophils are efficiently recruited under hypoxic conditions and promote angiogenesis, which could interfere with our VEGF-measurements [59]. Unfortunately, isolation of PBMCs was not possible due to technical equipment available in the glacier hut. Fourth, we performed the in vitro experiments under other climatic conditions on the mountain than in the experimental laboratory. However, the chosen oxygen level of $10 \% \mathrm{O}_{2}$ was calculated using established formula to simulate comparable hypoxic conditions as in our in vivo trial (see "Materials and Methods"). The oxygen level of $5 \% \mathrm{O}_{2}$ was chosen to further enhance the hypoxic effects in vitro, as it is known that PBMCs are exposed to more pronounced hypoxia within tissues or lymphatic tissue in vivo. Finally, as the study was performed in 2016, we used the unrevised LLS, which was valid at time of the study, which included insomnia. Thus, it remains unclear whether similar results can be obtained when the 2018 LLS is used [25].

\section{Conclusions}

In this prospective observational in vitro and in vivo trial, we have shown for the first time that the hypoxic-inflammatory response is differentially regulated following hypoxic and inflammatory stimulation in vitro and in vivo. In detail, exposure of healthy volunteers to acute hypobaric hypoxia with endurance exercise had a different and more pronounced effect on mRNA expression and cytokine release than isolated inflammatory or hypoxic incubation of PBMCs in vitro. Of note, both pro-inflammatory IL-1 $\beta$ and chemoattractant receptor CXCR-4 mRNA expression were associated with increased LLS and symptoms of AMS. Further studies are needed to elucidate the pathophysiological pathways linking IL-1 $\beta, C X C R-4$, and CCR-2 signaling pathways and risk for AMS. Furthermore, a study is planned to analyze whether PBMC stimulability differs between cells isolated under normoxia and cells isolated following $24 \mathrm{~h}$ under hypobaric hypoxia.

Supplementary Materials: Supplementary materials can be found at http://www.mdpi.com/1422-0067/21/3/1034/s1.

Author Contributions: T.K. and S.S. are the main authors of the manuscript. T.K., V.F., S.S. and M.R. were responsible for planning and execution of the trial. T.K., S.S., N.H., F.B., J.K. and C.S. were investigators and responsible for measurements at high altitude and hypoxic chamber. S.K., S.S. and V.F. were responsible for in vitro experiments and measurements of molecular variables in vivo. M.S. was involved in planning the trial 
and correction of the manuscript. M.H. was responsible for HIF-1 $\alpha$ protein visualization. All authors made significant contribution to the trial and have read and approved the final version of the manuscript.

Funding: The study was funded by a research grant from BEXMED (Deutsche Gesellschaft für Berg- und Expeditionsmedizin) to T.K. and from WIFOMED (Verein für Förderung von Wissenschaft und Forschung an der medizinischen Fakultät der Ludwig- Maximilians-Universität München) to S.S.

Acknowledgments: The authors would like to thank Walter Karlen from the Mobile Health Systems Lab, Department of Health Sciences and Technology, ETH Zurich, Switzerland, for developing the Android Tablet application for measurement of the AMS score and cognitive function as well as for evaluation of the data. We acknowledge support by the DFG Open Access Publication Fund of the Ruhr-Universität Bochum.

Conflicts of Interest: The authors have no conflicts of interest to declare.

\section{References}

1. Abe, T.; Kitaoka, Y.; Kikuchi, D.M.; Takeda, K.; Numata, O.; Takemasa, T. High-intensity interval training-induced metabolic adaptation coupled with an increase in Hif- $1 \alpha$ and glycolytic protein expression. J. Appl. Physiol. 2015, 119, 1297-1302. [CrossRef] [PubMed]

2. Lindholm, M.E.; Rundqvist, H. Skeletal muscle hypoxia-inducible factor-1 and exercise. Exp. Physiol. 2016, 101, 28-32. [CrossRef] [PubMed]

3. Liu, W.; Shen, S.-M.; Zhao, X.-Y.; Chen, G.-Q. Targeted genes and interacting proteins of hypoxia inducible factor-1. Int. J. Biochem. Mol. Biol. 2012, 3, 165-178. [PubMed]

4. Eltzschig, H.K.; Carmeliet, P. Hypoxia and inflammation. N. Engl. J. Med. 2011, 364, 656-665. [CrossRef] [PubMed]

5. Frede, S.; Berchner-Pfannschmidt, U.; Fandrey, J. Regulation of Hypoxia-Inducible Factors During Inflammation. In Methods in Enzymology; Academic Press: Camebridge, MA, USA, 2007; Vol. 435, pp. 403-419.

6. Schafer, S.T.; Frede, S.; Winning, S.; Bick, A.; Roshangar, P.; Fandrey, J.; Peters, J.; Adamzik, M. Hypoxia-inducible factor and target gene expression are decreased in patients with sepsis: Prospective observational clinical and cellular studies. Anesthesiology 2013, 118, 1426-1436. [CrossRef]

7. Hotchkiss, R.S.; Coopersmith, C.M.; McDunn, J.E.; Ferguson, T.A. The sepsis seesaw: Tilting toward immunosuppression. Nat. Med. 2009, 15, 496-497. [CrossRef]

8. Frede, S.; Stockmann, C.; Freitag, P.; Fandrey, J. Bacterial lipopolysaccharide induces HIF-1 activation in human monocytes via p44/42 MAPK and NF-кB. Biochem. J. 2006, 396, 517-527. [CrossRef]

9. Frede, S.; Stockmann, C.; Winning, S.; Freitag, P.; Fandrey, J. Hypoxia-inducible factor (HIF) 1alpha accumulation and HIF target gene expression are impaired after induction of endotoxin tolerance. J. Immunol. 2009, 182, 6470-6476. [CrossRef]

10. Winning, S.; Splettstoesser, F.; Fandrey, J.; Frede, S. Acute hypoxia induces HIF-independent monocyte adhesion to endothelial cells through increased intercellular adhesion molecule-1 expression: The role of hypoxic inhibition of prolyl hydroxylase activity for the induction of NF-kappa B. J. Immunol. 2010, 185, 1786-1793. [CrossRef]

11. Zepeda, A.B.; Pessoa, A.; Castillo, R.L.; Figueroa, C.A.; Pulgar, V.M.; Farías, J.G. Cellular and molecular mechanisms in the hypoxic tissue: Role of HIF-1 and ROS. Cell Biochem. Funct. 2013, 31, 451-459. [CrossRef]

12. Drewry, A.M.; Hotchkiss, R.S. Revising definitions of sepsis. Nat. Rev. Nephrol. 2015, 11, 326-328. [CrossRef] [PubMed]

13. Seeley, J.J.; Ghosh, S. Molecular mechanisms of innate memory and tolerance to LPS. J. Leukoc. Biol. 2017, 101, 107-119. [CrossRef] [PubMed]

14. Ward, P.A. The sepsis seesaw: Seeking a heart salve. Nat. Med. 2009, 15, 497-498. [CrossRef]

15. Buroker, N.E.; Ning, X.-H.; Zhou, Z.-N.; Li, K.; Cen, W.-J.; Wu, X.-F.; Zhu, W.-Z.; Scott, C.R.; Chen, S.-H. EPAS1 and EGLN1 associations with high altitude sickness in Han and Tibetan Chinese at the Qinghai-Tibetan Plateau. Blood Cells Mol. Dis. 2012, 49, 67-73. [CrossRef] [PubMed]

16. Buroker, N.E.; Ning, X.-H.; Zhou, Z.-N.; Li, K.; Cen, W.-J.; Wu, X.-F.; Zhu, W.-Z.; Scott, C.R.; Chen, S.-H. SNPs, linkage disequilibrium, and chronic mountain sickness in Tibetan Chinese. Hypoxia 2017, 5, 67-74. [CrossRef] [PubMed]

17. Zhang, E.; Zhang, J.; Jin, J.; Qin, J.; Li, H.; Huang, L. Variants of the low oxygen sensors EGLN1 and HIF-1AN associated with acute mountain sickness. Int. J. Mol. Sci. 2014, 15, 21777-21787. [CrossRef] 
18. Song, D.; Li, L.-S.; Arsenault, P.R.; Tan, Q.; Bigham, A.W.; Heaton-Johnson, K.J.; Master, S.R.; Lee, F.S. Defective Tibetan PHD2 binding to p23 links high altitude adaption to altered oxygen sensing. J. Biol. Chem. 2014, 289, 14656-14665. [CrossRef]

19. Mazzeo, R.S. Altitude, exercise and immune function. Exerc. Immunol. Rev. 2005, 11, 6-16.

20. Swenson, E.R. Hypoxic pulmonary vasoconstriction. High. Alt. Med. Biol. 2013, 14, 101-110. [CrossRef]

21. Labrousse-Arias, D.; Castillo-González, R.; Rogers, N.M.; Torres-Capelli, M.; Barreira, B.; Aragonés, J.; Cogolludo, Á.; Isenberg, J.S.; Calzada, M.J. HIF-2 $\alpha$-mediated induction of pulmonary thrombospondin-1 contributes to hypoxia-driven vascular remodelling and vasoconstriction. Cardiovasc. Res. 2016, 109, 115-130. [CrossRef]

22. Dötsch, A.; Eisele, L.; Rabeling, M.; Rump, K.; Walstein, K.; Bick, A.; Cox, L.; Engler, A.; Bachmann, H.S.; Jöckel, K.-H.; et al. Hypoxia Inducible Factor-2 Alpha and Prolinhydroxylase 2 Polymorphisms in Patients with Acute Respiratory Distress Syndrome (ARDS). Int. J. Mol. Sci. 2017, 18. [CrossRef] [PubMed]

23. Höcker, A.; Rabeling, M.; Bick, A.; Cox, L.; Kreuzer, M.; Engler, A.; Walstein, K.; Bachmann, H.S.; Jöckel, K.-H.; Eisele, L.; et al. Hypoxia inducible factor-1 alpha and prolinhydroxlase 2 polymorphisms in patients with severe sepsis: A prospective observational trial. BMC Anesthesiol. 2016, 16, 656-659. [CrossRef] [PubMed]

24. Kammerer, T.; Faihs, V.; Hulde, N.; Bayer, A.; Hübner, M.; Brettner, F.; Karlen, W.; Kröpfl, J.M.; Rehm, M.; Spengler, C.; et al. Changes of hemodynamic and cerebral oxygenation after exercise in normobaric and hypobaric hypoxia: Associations with acute mountain sickness. Ann. Occup. Environ. Med. 2018, $30,66$. [CrossRef]

25. Roach, R.C.; Hackett, P.H.; Oelz, O.; Bärtsch, P.; Luks, A.M.; MacInnis, M.J.; Baillie, J.K. Lake Louise AMS Score Consensus Committee The 2018 Lake Louise Acute Mountain Sickness Score. High. Alt. Med. Biol. 2018, 19, 4-6. [CrossRef]

26. Schaber, M.; Leichtfried, V.; Fries, D.; Wille, M.; Gatterer, H.; Faulhaber, M.; Würtinger, P.; Schobersberger, W. Influence of Acute Normobaric Hypoxia on Hemostasis in Volunteers with and without Acute Mountain Sickness. Biomed. Res. Int. 2015, 2015, 593938. [CrossRef] [PubMed]

27. Li, P.; Deng, J.; Wei, X.; Jayasuriya, C.T.; Zhou, J.; Chen, Q.; Zhang, J.; Wei, L.; Wei, F. Blockade of hypoxia-induced CXCR4 with AMD3100 inhibits production of OA-associated catabolic mediators IL-1 $\beta$ and MMP-13. Mol. Med. Rep. 2016, 14, 1475-1482. [CrossRef]

28. Dai, T.; Hu, Y.; Zheng, H. Hypoxia increases expression of CXC chemokine receptor 4 via activation of PI3K/Akt leading to enhanced migration of endothelial progenitor cells. Eur. Rev. Med. Pharmacol. Sci. 2017, 21, 1820-1827.

29. Choi, S.; Chung, H.; Hong, H.; Kim, S.Y.; Kim, S.-E.; Seoh, J.-Y.; Moon, C.M.; Yang, E.G.; Oh, E.-S. Inflammatory hypoxia induces syndecan-2 expression through IL-1 $\beta$-mediated FOXO3a activation in colonic epithelia. FASEB J. 2017, 31, 1516-1530. [CrossRef]

30. De Vries, H.E.; Blom-Roosemalen, M.C.M.; van Oosten, M.; de Boer, A.G.; van Berkel, T.J.C.; Breimer, D.D.; Kuiper, J. The influence of cytokines on the integrity of the blood-brain barrier in vitro. J. Neuroimmunol. 1996, 64, 37-43. [CrossRef]

31. Wang, C.; Jiang, H.; Duan, J.; Chen, J.; Wang, Q.; Liu, X.; Wang, C. Exploration of Acute Phase Proteins and Inflammatory Cytokines in Early Stage Diagnosis of Acute Mountain Sickness. High. Alt. Med. Biol. 2018, 19, 170-177. [CrossRef]

32. Momcilović, M.; Mostarica-Stojković, M.; Miljković, D. CXCL12 in control of neuroinflammation. Immunol. Res. 2012, 52, 53-63. [CrossRef] [PubMed]

33. Li, M.; Ransohoff, R.M. Multiple roles of chemokine CXCL12 in the central nervous system: A migration from immunology to neurobiology. Prog. Neurobiol. 2008, 84, 116-131. [CrossRef] [PubMed]

34. Zhou, Y.; Huang, X.; Zhao, T.; Qiao, M.; Zhao, X.; Zhao, M.; Xu, L.; Zhao, Y.; Wu, L.; Wu, K.; et al. Hypoxia augments LPS-induced inflammation and triggers high altitude cerebral edema in mice. Brain Behav. Immun. 2017, 64, 266-275. [CrossRef] [PubMed]

35. Manthiram, K.; Zhou, Q.; Aksentijevich, I.; Kastner, D.L. The monogenic autoinflammatory diseases define new pathways in human innate immunity and inflammation. Nat. Immunol. 2017, 18, 832-842. [CrossRef]

36. Giesbrecht, K.; Eberle, M.-E.; Wölfle, S.J.; Sahin, D.; Sähr, A.; Oberhardt, V.; Menne, Z.; Bode, K.A.; Heeg, K.; Hildebrand, D. IL-1 $\beta$ As Mediator of Resolution That Reprograms Human Peripheral Monocytes toward a Suppressive Phenotype. Front. Immunol. 2017, 8. [CrossRef] 
37. Liu, B.; Chen, J.; Zhang, L.; Gao, Y.; Cui, J.; Zhang, E.; Xu, G.; Liang, Y.; Liang, Y.; Wang, J.; et al. IL-10 Dysregulation in Acute Mountain Sickness Revealed by Transcriptome Analysis. Front. Immunol. 2017, 8, 628. [CrossRef]

38. Lundeberg, J.; Feiner, J.R.; Schober, A.; Sall, J.W.; Eilers, H.; Bickler, P.E. Increased Cytokines at High Altitude: Lack of Effect of Ibuprofen on Acute Mountain Sickness, Physiological Variables, or Cytokine Levels. High. Alt. Med. Biol. 2018, 19, 249-258. [CrossRef]

39. Swenson, E.R.; MacDonald, A.; Vatheuer, M.; Maks, C.; Treadwell, A.; Allen, R.; Schoene, R.B. Acute mountain sickness is not altered by a high carbohydrate diet nor associated with elevated circulating cytokines. Aviat. Space Environ. Med. 1997, 68, 499-503.

40. Schild, M.; Eichner, G.; Beiter, T.; Zügel, M.; Krumholz-Wagner, I.; Hudemann, J.; Pilat, C.; Krüger, K.; Niess, A.M.; Steinacker, J.M.; et al. Effects of Acute Endurance Exercise on Plasma Protein Profiles of Endurance-Trained and Untrained Individuals over Time. Mediators Inflamm. 2016, 2016, 4851935. [CrossRef]

41. Barron, A.M.; Tokunaga, M.; Zhang, M.-R.; Ji, B.; Suhara, T.; Higuchi, M. Assessment of neuroinflammation in a mouse model of obesity and $\beta$-amyloidosis using PET. J. Neuroinflamm. 2016, 13, 221. [CrossRef]

42. Prendergast, C.T.; Anderton, S.M. Immune cell entry to central nervous system-Current understanding and prospective therapeutic targets. Endocr. Metab. Immune Disord. Drug Targets 2009, 9, 315-327. [CrossRef]

43. Mojsilovic-Petrovic, J.; Callaghan, D.; Cui, H.; Dean, C.; Stanimirovic, D.B.; Zhang, W. Hypoxia-inducible factor-1 (HIF-1) is involved in the regulation of hypoxia-stimulated expression of monocyte chemoattractant protein-1 (MCP-1/CCL2) and MCP-5 (Ccl12) in astrocytes. J. Neuroinflamm. 2007, 4, 12. [CrossRef] [PubMed]

44. Tian, D.-S.; Peng, J.; Murugan, M.; Feng, L.-J.; Liu, J.-L.; Eyo, U.B.; Zhou, L.-J.; Mogilevsky, R.; Wang, W.; $\mathrm{Wu}, \mathrm{L} .-\mathrm{J}$. Chemokine CCL2-CCR2 Signaling Induces Neuronal Cell Death via STAT3 Activation and IL-1 $\beta$ Production after Status Epilepticus. J. Neurosci. 2017, 37, 7878-7892. [CrossRef] [PubMed]

45. Palazon, A.; Tyrakis, P.A.; Macias, D.; Veliça, P.; Rundqvist, H.; Fitzpatrick, S.; Vojnovic, N.; Phan, A.T.; Loman, N.; Hedenfalk, I.; et al. An HIF-1 $\alpha$ /VEGF-A Axis in Cytotoxic T Cells Regulates Tumor Progression. Cancer Cell 2017, 32, 669-683.e5. [CrossRef] [PubMed]

46. Hu, K.; Babapoor-Farrokhran, S.; Rodrigues, M.; Deshpande, M.; Puchner, B.; Kashiwabuchi, F.; Hassan, S.J.; Asnaghi, L.; Handa, J.T.; Merbs, S.; et al. Hypoxia-inducible factor 1 upregulation of both VEGF and ANGPTL4 is required to promote the angiogenic phenotype in uveal melanoma. Oncotarget 2016, 7 , 7816-7828. [CrossRef]

47. Hassan, A.; Arnold, B.M.; Caine, S.; Toosi, B.M.; Verge, V.M.K.; Muir, G.D. Acute intermittent hypoxia and rehabilitative training following cervical spinal injury alters neuronal hypoxia- and plasticity-associated protein expression. PLoS ONE 2018, 13, e0197486. [CrossRef] [PubMed]

48. Tsuchiya, M.; Tokai, H.; Takehara, Y.; Haraguchi, Y.; Asada, A.; Utsumi, K.; Inoue, M. Interrelation between oxygen tension and nitric oxide in the respiratory system. Am. J. Respir. Crit. Care Med. 2000, 162, 1257-1261. [CrossRef]

49. Westendorf, A.M.; Skibbe, K.; Adamczyk, A.; Buer, J.; Geffers, R.; Hansen, W.; Pastille, E.; Jendrossek, V. Hypoxia Enhances Immunosuppression by Inhibiting CD4+ Effector T Cell Function and Promoting Treg Activity. Cell. Physiol. Biochem. 2017, 41, 1271-1284. [CrossRef]

50. Hatfield, S.; Veszeleiova, K.; Steingold, J.; Sethuraman, J.; Sitkovsky, M. Mechanistic Justifications of Systemic Therapeutic Oxygenation of Tumors to Weaken the Hypoxia Inducible Factor $1 \alpha$-Mediated Immunosuppression. Adv. Exp. Med. Biol. 2019, 1136, 113-121.

51. Schäfer, S.T.; Gessner, S.; Scherag, A.; Rump, K.; Frey, U.H.; Siffert, W.; Westendorf, A.M.; Steinmann, J.; Peters, J.; Adamzik, M. Hydrocortisone Fails to Abolish NF-кB1 Protein Nuclear Translocation in Deletion Allele Carriers of the NFKB1 Promoter Polymorphism (-94ins/delATTG) and Is Associated with Increased 30-Day Mortality in Septic Shock. PLoS ONE 2014, 9, e104953. [CrossRef]

52. Fenn, W.O.; Rahn, H.; Otis, A.B. A theoretical study of the composition of the alveolar air at altitude. Am. J. Physiol. 1946, 146, 637-653. [CrossRef] [PubMed]

53. Richard, N.A.; Koehle, M.S. Differences in cardio-ventilatory responses to hypobaric and normobaric hypoxia: A review. Aviat. Space Environ. Med. 2012, 83, 677-684. [CrossRef] [PubMed]

54. Van der Heide, V.; Möhnle, P.; Rink, J.; Briegel, J.; Kreth, S. Down-regulation of MicroRNA-31 in CD4+ T Cells Contributes to Immunosuppression in Human Sepsis by Promoting TH2 Skewing. Anesthesiology 2016, 124, 908-922. [CrossRef] [PubMed] 
55. Schäfer, S.T.; Franken, L.; Adamzik, M.; Schumak, B.; Scherag, A.; Engler, A.; Schönborn, N.; Walden, J.; Koch, S.; Baba, H.A.; et al. Mitochondrial DNA: An Endogenous Trigger for Immune Paralysis. Anesthesiology 2016, 124, 923-933. [CrossRef] [PubMed]

56. Rosales, C. Neutrophil: A Cell with Many Roles in Inflammation or Several Cell Types? Front. Physiol. 2018, 9, 113. [CrossRef]

57. Chavakis, E.; Choi, E.Y.; Chavakis, T. Novel aspects in the regulation of the leukocyte adhesion cascade. Thromb. Haemost. 2009, 102, 191-197. [CrossRef]

58. Martin, C.; Burdon, P.C.E.; Bridger, G.; Gutierrez-Ramos, J.C.; Williams, T.J.; Rankin, S.M. Chemokines acting via CXCR2 and CXCR4 control the release of neutrophils from the bone marrow and their return following senescence. Immunity 2003, 19, 583-593. [CrossRef]

59. Massena, S.; Christoffersson, G.; Vågesjö, E.; Seignez, C.; Gustafsson, K.; Binet, F.; Herrera Hidalgo, C.; Giraud, A.; Lomei, J.; Weström, S.; et al. Identification and characterization of VEGF-A-responsive neutrophils expressing CD49d, VEGFR1, and CXCR4 in mice and humans. Blood 2015, 126, 2016-2026. [CrossRef]

(C) 2020 by the authors. Licensee MDPI, Basel, Switzerland. This article is an open access article distributed under the terms and conditions of the Creative Commons Attribution (CC BY) license (http://creativecommons.org/licenses/by/4.0/). 